\title{
Do wild tamarins reconcile? Two case reports from moustached tamarins
}

\author{
Eckhard W. Heymann ${ }^{1}$ (D)
}

Received: 7 May 2020 / Revised: 28 September 2020 / Accepted: 15 October 2020 / Published online: 23 October 2020

(C) The Author(s) 2020

\begin{abstract}
Mechanisms of conflict resolution, e.g. reconciliation, have been reported from a number of group-living animals, particularly primates. However, whether or not conflict resolution occurs in the cooperatively breeding callitrichids (marmosets and tamarins) remains a matter of debate. Captive studies provide contrasting evidence for the occurrence of reconciliation, and no evidence has been previously available for wild groups. Here, I present data on post-conflict behaviour in wild moustached tamarins, Saguinus mystax, which suggest that reconciliation occurs among wild callitrichids, too. However, reconciliation seems to occur very rarely among these primates, probably due to the generally peaceful nature of their social relations.
\end{abstract}

Keywords Saguinus mystax · Aggression · Affiliation · Post-conflict behaviour

\section{Introduction}

Group living provides benefits to group members, e.g. reduced predation risk, but also creates conflicts among group members over resources like food and mates (Danchin et al. 2008; Krause and Ruxton 2002). Conflicts may disrupt social relations thereby compromising the stability and integrity of groups. Therefore, mechanisms such as reconciliation have evolved to modulate and resolve conflicts (Aureli and de Waal 2000). Reconciliation occurs when former opponents interact non-agonistically after a conflict, thus reducing the probability of further conflicts (Aureli and van Schaik 1991; de Waal and van Roosmalen 1979). Reconciliation has been demonstrated in a number of different primate and nonprimate species (Arnold and Aureli 2007; Fraser and Bugnyar 2011; Lazzaroni et al. 2017). For callitrichid primates (marmosets and tamarins), evidence for reconciliatory behaviour is conflicting: while it has not been observed in captive red-bellied tamarins, Saguinus labiatus (Schaffner and Caine 2000; Schaffner et al. 2005), it is present in captive common marmosets, Callithrix jacchus, and captive cotton-

Eckhard W. Heymann

eheyman@gwdg.de

1 Verhaltensökologie \& Soziobiologie, Deutsches Primatenzentrum Leibniz-Institut für Primatenforschung, Kellnerweg 4,

37077 Göttingen, Germany top tamarins, Saguinus oedipus (Peñate et al. 2009; Westlund et al. 2000). To date, no researchers have published accounts of reconciliatory behaviour among wild callitrichids.

In this paper, I report observations on two behavioural events in wild moustached tamarins, Saguinus mystax, where one individual acted aggressively towards a group mate and then immediately showed affiliative behaviour towards that same individual.

Moustached tamarins live in groups of 3-10, rarely more individuals with a high level of genetic relatedness (Heymann 2000; Huck et al. 2005; Löttker et al. 2004). Breeding is usually restricted to a single adult female, resulting in a high reproductive skew among females (Garber 1997). Breeding females may mate with multiple adult males in the group, and adult males are generally the main infant carriers (Garber 1997; Heymann 1990; Huck et al. 2004). Since other group members also participate in infant carrying, S. mystax are considered as cooperative breeders (Garber 1997). Allogrooming is the principal social interaction, and aggression is very rare (Heymann 1996). The anecdotal nature of the observations precludes the rigid statistical test demanded to demonstrate this is reconciliation (Kappeler and van Schaik 1992). However, I discuss these observations in the context of theoretical consideration on why reconciliation should be absent or rare in cooperatively breeding animals (Kutsukake and Clutton-Brock 2008; Schaffner and Caine 2000). 


\section{Methods}

The observations reported here were made during field work at the Estación Biológica Quebrada Blanco (EBQB) in northeastern Peruvian Amazonia ( $4^{\circ} 21^{\prime} \mathrm{S} 73^{\circ} 09^{\prime} \mathrm{W}$ ). At EBQB, behavioural and ecological research on tamarins is conducted since 1985. Groups of $S$. mystax at EBQB are very well habituated to the presence of human observers to observe them at close range.

The first observation was made in 1995 while collecting behavioural data of a group of $S$. mystax ( 2 adult males, 2 adult females, 1 subadult male, 1 juvenile male, and 1 juvenile female) through instantaneous scan sampling at 10-min intervals and continuous recording of social interactions. The second observation was made in 2010 during a field course while the author was video-recording a grooming session of three $S$. mystax, members of a group of 2 adult males, 1 adult female, 1 subadult male, and 1 subadult female.

Tamarins can be individually distinguished by body size; size, shape, and pigmentation of genitals; and permanent natural markings (Löttker et al. 2004). The group observed in 2010 did not include any of the animals of the group in 1995.

\section{Results}

I observed two cases in which an act of aggression was immediately followed by affiliative behaviour of the aggressor towards the target of the aggression.

\section{Case 1 (28 August 1995)}

$1100 \mathrm{~h}$ The group starts resting and allogrooming.

$1149 \mathrm{~h}$ Adult male B starts grooming the subadult male; other group members are resting and allogrooming, including the adult female who is about $2 \mathrm{~m}$ away.

$1153 \mathrm{~h}$ Adult male B stops grooming the subadult male, and both move towards the adult female. Upon arrival at the adult female, adult male B lunges at the subadult male. Immediately after the lunge, adult male B starts grooming the subadult male and continues until $1205 \mathrm{~h}$. Then, both males simultaneously groom the adult female.

\section{Case 2 (5 October 2010)}

At around $1200 \mathrm{~h}$, the tamarin group started resting and grooming on a small treefall gap. The grooming session and associated events involved one adult male, the subadult male, and the subadult female. Timeline (minutes:seconds) from the video (available at https://zenodo.org/record/3237722).
00:00 Adult male grooms subadult male; subadult female forages on the same trunk some $40-50 \mathrm{~cm}$ away (Fig. 1a).

00:12 Subadult female stops foraging and approaches the grooming males (Fig. 1b).

00:14 Subadult female starts grooming adult male 2 (Fig. 1c).

00:20 Adult male stops grooming, grabs at the subadult female, and bites into her neck (Fig. 1d); subadult female gives a bared-teeth squeal (Coates and Poole 1983) (Fig. 1e).

00:22 Adult male and subadult female continue grooming of subadult male (Fig. 1f).

01:28 Adult male stops grooming, grabs at subadult female, and bites into her head/neck, more intensively than at 00:20 (Fig. 1g).

01:29 Subadult female gives a bared-teeth squeal, more intensively than at 00:20 (Fig. 1h).

01:33 Adult male starts grooming subadult female (Fig. 1i).

The grooming of the subadult female by the adult male continued for 3:25 $\mathrm{min}$. Then, the adult male started to groom the subadult male while the subadult female remained resting in between the two males.

In neither case did I see an obvious stimulus that might have triggered the aggression.

\section{Discussion}

In their predictive framework of conflict resolution, Aureli et al. (2002) posited that reconciliation and other postconflict reunions are not required in animal societies where aggression is rare. Furthermore, Kutsukake and CluttonBrock (2008) argued that reconciliation and other mechanisms of conflict resolution are less important in animal societies with a high reproductive skew. In fact, aggression rates are very low in tamarins, both in captivity and the wild (Heymann 1996; Schaffner and Caine 2000), and reproductive skew is high in female tamarins, with breeding generally being monopolized by a single adult female per group (French 1997; but see Culot et al. 2011). Therefore, on theoretical grounds, reconciliation and other mechanisms of conflict resolution are expected to be are or absent in tamarins and other callitrichids. Captive studies demonstrated the occurrence of reconciliation in callitrichids (Peñate et al. 2009; Westlund et al. 2000), but previously, there were no reports of this behaviour occurring in wild groups. Albeit anecdotal in nature, this paper indicates that reconciliation occurs in wild callitrichids, too.

Aggressive acts immediately followed by grooming of the victim were observed in S. mystax by Laurence Culot (pers. comm.: 1 group, September 2005-May 2008, 2303 contact 

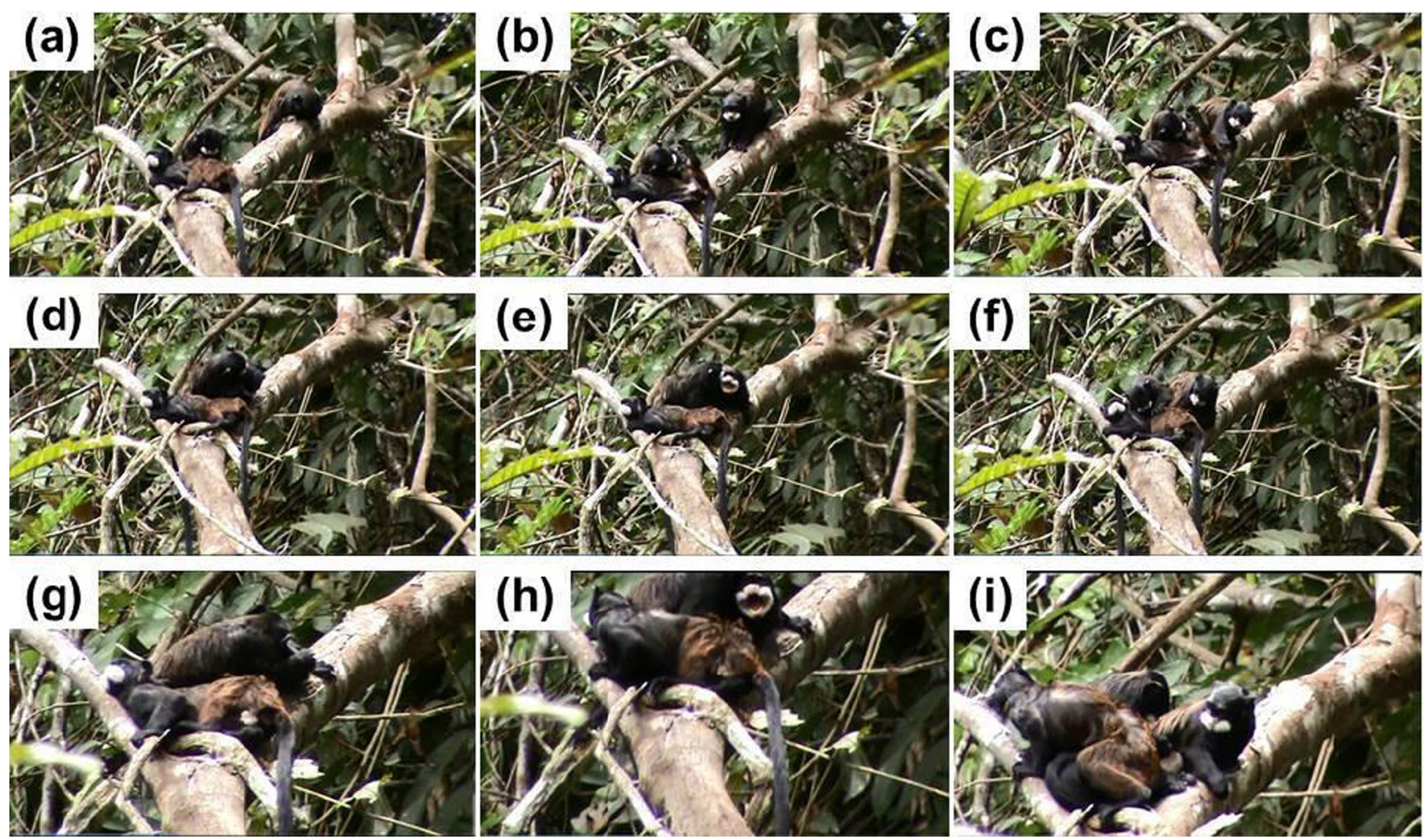

Fig. 1 See the description of case 2 for details of each scene

hours [see Culot et al. 2010]) and Mojca Stojan-Dolar (pers. comm.: 4 groups, February 2006-March 2007, ca. 1800 contact hours [see Stojan-Dolar and Heymann 2010]). Since these studies did not focus on social behaviour, no details were recorded. In a study on the social behaviour and mating system of S. mystax (Maren Huck and Petra Löttker, pers. comm.; 2 groups, January-December 2001, 6261 contact hours [see Huck et al. 2004]), no reconciliation was observed. This suggests that reconciliation is extremely rare, in line with theoretical predictions. Reconciliation has not been observed in studies on social behaviour and communication of sympatrically living black-fronted tamarins, Leontocebus nigrifrons (Yvan Lledo-Ferrer, pers. comm.: 3 groups, 1363 contact hours [see Lledo Ferrer et al. 2011]; Darja Slana, pers. comm.: 5 groups, May 2012-August 2013, 3868.7 contact hours [see Slana 2019]). There are no marked differences in social organization and behaviour between $S$. mystax and L. nigrifrons, although the number of adult males and females per group seems to be lower in the latter and the two species differ in patterns of olfactory communication (Heymann 2000, 2001). The extent to which other wild callitrichids employ reconciliation as mechanism of conflict resolution and whether interspecific differences exist remains to be determined. In conclusion, the two cases reported here indicate that reconciliation is a behavioural option available to wild callitrichids, at least tamarins, but that it is an extremely rare behaviour, probably due to the generally peaceful nature of their social relations, so that many observation hours must be accumulated to be recorded at all.

Acknowledgements The field study during which the observation was made in 1995 was authorized by the Regional Ministry of Agriculture in Iquitos (authorization no. 009-95-GRL-CTAR-DRA) and supported by the Deutsche Forschungsgemeinschaft (HE 1870/3-2). I thank Juan Huanaquiri Huayllahua for skilful field assistance during the study in 1995. I am grateful to Maren Huck, Petra Löttker, Laurence Culot, Yvan Lledo-Ferrer, Mojca Stojan-Dolar, and Darja Slana for personal communication and to the two anonymous reviewers for very helpful comments.

Funding Open Access funding enabled and organized by Projekt DEAL. The 1995 field study during which one of the cases reported in this manuscript was observed was supported by the Deutsche Forschungsgemeinschaft (HE 1870/3-2).

Availability of data and material The video recording of one of the cases reported in this manuscript is available at https://zenodo.org/record/ 3237722 .

\section{Compliance with ethical standards}

Conflicts of interest The author declares that there are no conflicts of interest.

Ethics approval Field research adhered to the "Guidelines for the treatment of animals in behavioural research and teaching" of the Association for the Study of Animal Behaviour and the Animal Behavior Society and 
to the "Code of Best Practices for Field Primatology" of the American Society of Primatologists.

\section{Consent to participate Not applicable}

Consent for publication Not applicable

Code availability Not applicable

Open Access This article is licensed under a Creative Commons Attribution 4.0 International License, which permits use, sharing, adaptation, distribution and reproduction in any medium or format, as long as you give appropriate credit to the original author(s) and the source, provide a link to the Creative Commons licence, and indicate if changes were made. The images or other third party material in this article are included in the article's Creative Commons licence, unless indicated otherwise in a credit line to the material. If material is not included in the article's Creative Commons licence and your intended use is not permitted by statutory regulation or exceeds the permitted use, you will need to obtain permission directly from the copyright holder. To view a copy of this licence, visit http://creativecommons.org/licenses/by/4.0/.

\section{References}

Arnold K, Aureli F (2007) Postconflict reconciliation. In: Campbell CJ, Fuentes A, Mackinnon KC, Panger M, Bearder SK (eds) Primates in perspective. Oxford University Press, Oxford, pp 592-608

Aureli F, de Waal FBM (2000) Natural conflict resolution. University of California Press, Berkeley

Aureli F, van Schaik CP (1991) Post-conflict behaviour in long-tailed macaques (Macaca fascicularis) I. The social events. Ethology 89: $89-100$

Aureli F, Cords M, van Schaik CP (2002) Conflict resolution following aggression in gregarious animals: a predictive framework. Anim Behav 64:325-343

Coates A, Poole TB (1983) The behavior of the callitrichid monkey, Saguinus labiatus labiatus, in the laboratory. Int J Primatol 4:339371

Culot L, Muñoz Lazo FJJ, Poncin P, Huynen MC, Heymann EW (2010) Seasonal variation in seed dispersal by tamarins alters seed rain in a secondary rainforest. Int J Primatol 31:553-569

Culot L, Lledo Ferrer Y, Hoelscher O, Muñoz Lazo FJJ, Huynen MC, Heymann EW (2011) Reproductive failure, possible maternal infanticide, and cannibalism in wild moustached tamarins, Saguinus mystax. Primates 52:179-186

Danchin E, Giraldeau L-A, Wagner RH (2008) Animal aggregations: hypotheses and controversies. In: Danchin E, Giraldeau L-A, Cézilly F (eds) Behavioural ecology. Oxford University Press, Oxford, pp 503-545

de Waal FBM, van Roosmalen A (1979) Reconciliation and consolation among chimpanzees. Behav Ecol Sociobiol 5:55-66

Fraser ON, Bugnyar T (2011) Ravens reconcile after aggressive conflicts with valuable partners. PLoS One 6:e18118

French JA (1997) Proximate regulation of singular breeding in callitrichid primates. In: Solomon NG, French JA (eds) Cooperative breeding in mammals. Cambridge University Press, Cambridge, pp 34-75
Garber PA (1997) One for all and breeding for one: cooperation and competition as a tamarin reproductive strategy. Evol Anthropol 5: 187-199

Heymann EW (1990) Social behaviour and infant carrying in a group of moustached tamarins, Saguinus mystax (Primates: Platyrrhini: Callitrichidae), on Padre Isla, Peruvian Amazonia. Primates 31: 183-196

Heymann EW (1996) Social behavior of wild moustached tamarins, Saguinus mystax, at the Estación Biológica Quebrada Blanco, Peruvian Amazonia. Am J Primatol 38:101-113

Heymann EW (2000) The number of adult males in callitrichine groups and its implications for callitrichine social evolution. In: Kappeler $\mathrm{P}$ (ed) Primate Males. Cambridge University Press, Cambridge, pp 64-71

Heymann EW (2001) Interspecific variation of scent-marking behaviour in wild tamarins, Saguinus mystax and Saguinus fuscicollis. Folia Primatol 72:253-267

Huck M, Löttker P, Heymann EW (2004) The many faces of helping: possible costs and benefits of infant carrying and food transfer in wild moustached tamarins (Saguinus mystax). Behaviour 141:915934

Huck M, Löttker P, Böhle U-R, Heymann EW (2005) Paternity and kinship patterns in polyandrous moustached tamarins (Saguinus mystax). Am J Phys Anthropol 127:449-464

Kappeler PM, van Schaik CP (1992) Methodological and evolutionary aspects of reconciliation among primates. Ethology 92:51-69

Krause J, Ruxton GD (2002) Living in groups. Oxford University Press, Oxford

Kutsukake N, Clutton-Brock TH (2008) Do meerkats engage in conflict management following aggression? Reconciliation, submission and avoidance. Anim Behav 75:1441-1453

Lazzaroni M, Marshall-Pescini S, Cafazzo S (2017) Post-conflict opponent affiliation reduces victim re-aggression in a family group of captive arctic wolves (Canis lupus arctos). PLoS One 12:e187450

Lledo Ferrer Y, Peláez F, Heymann EW (2011) The equivocal relationship between territoriality and scent marking in wild saddleback tamarins, Saguinus fuscicollis. Int J Primatol 32:974-991

Löttker P, Huck M, Heymann EW (2004) Dynamic stability or stable dynamics? Demographic parameters and events in wild moustached tamarins (Saguinus mystax). Am J Primatol 64:425-449

Peñate L, Peláez F, Sánchez S (2009) Reconciliation in captive cotton-top tamarins (Saguinus oedipus), a cooperative breeding primate. Am J Primatol 71:895-900

Schaffner CM, Caine NG (2000) The peacefulness of cooperatively breeding primates. In: Aureli F, de Waal F (eds) Natural conflict resolution. University of California Press, Berkeley, pp 155-169

Schaffner CM, Aureli F, Caine NG (2005) Following the rules: why small groups of tamarins do not reconcile conflicts. Folia Primatol 76:6776

Slana D (2019) Mating systems and infant care of cooperatively breeding black-fronted tamarins (Leontocebus nigrifrons). Doctoral thesis, Georg-August Universität Göttingen

Stojan-Dolar M, Heymann EW (2010) Vigilance of mustached tamarins in single-species and mixed-species groups the influence of group composition. Behav Ecol Sociobiol 64:325-335

Westlund K, Ljungberg T, Borefelt U, Abrahamsson C (2000) Postconflict affiliation in common marmosets (Callithrix jacchus jacchus). Am J Primatol 52:31-46

Publisher's note Springer Nature remains neutral with regard to jurisdictional claims in published maps and institutional affiliations. 